\title{
MANAGEMENT OF ENDOCRINE DISEASE Reversible hypogonadotropic hypogonadism
}

\author{
Andrew A Dwyer1, Taneli Raivio ${ }^{2,3}$ and Nelly Pitteloud ${ }^{1,4}$ \\ ${ }^{1}$ Endocrinology, Diabetes and Metabolism Service of the Centre Hospitalier Universitaire Vaudois (CHUV), Rue du \\ Bugnon 46, 1011 Lausanne, Switzerland, ²Faculty of Medicine/Physiology, University of Helsinki, Helsinki, Finland, \\ ${ }^{3}$ The Children's Hospital, Helsinki University Central Hospital (HUCH), Helsinki, Finland and ${ }^{4}$ Department of \\ Physiology, Faculty of Biology and Medicine, University of Lausanne, Rue du Bugnon 7, 1005 Lausanne, Switzerland
}

Correspondence should be addressed to N Pitteloud

Email

nelly.pitteloud@chuv.ch

\begin{abstract}
Congenital hypogonadotropic hypogonadism $(\mathrm{CHH})$ is characterized by lack of puberty and infertility. Traditionally, it has been considered a life-long condition yet cases of reversibility have been described wherein patients spontaneously recover function of the reproductive axis following treatment. Reversibility occurs in both male and female $\mathrm{CHH}$ cases and appears to be more common $(\sim 10-15 \%)$ than previously thought. These reversal patients span a range of GnRH deficiency from mild to severe and many reversal patients harbor mutations in genes underlying $\mathrm{CHH}$. However, to date there are no clear factors for predicting reversible $\mathrm{CHH}$. Importantly, recovery of reproductive axis function may not be permanent. Thus, $\mathrm{CHH}$ is not always life-long and the incidence of reversal warrants periodic treatment withdrawal with close monitoring and follow-up. Reversible $\mathrm{CHH}$ highlights the importance of environmental (epigenetic) factors such as sex steroid treatment on the reproductive axis in modifying the phenotype. This review provides an overview and an update on what is known about this phenomenon.
\end{abstract}

\section{Introduction}

In humans, puberty and reproduction are contingent upon the pulsatile secretion of gonadotropin-releasing hormone $(\mathrm{GnRH})$ from hypothalamic neurons. This neuroendocrine activity stimulates the secretion of gonadotropins (luteinizing hormone (LH) and follicle stimulating hormone (FSH)) from the gonadotropes that in turn stimulate the gonads to produce sex steroids (testosterone and estradiol) and gametes (sperm and ova). Congenital hypogonadotropic hypogonadism $(\mathrm{CHH})$ is a congenital disorder caused by the deficient secretion or action of $\mathrm{GnRH}$ and is clinically characterized by incomplete or absent puberty and infertility (1). Notably, the onset and severity of GnRH deficiency ranges from severe (e.g. complete absence of puberty with cryptorchidism and micropenis) (2) to relatively milder forms as demonstrated by enfeebled GnRH-induced LH secretion and partial pubertal development (3). The latter includes the so-called 'fertile eunuch' variant (4) who have sufficient gonadotropin secretion for some testicular growth capable of supporting spermatogenesis yet who

\section{Invited Author's profile}

Professor Nelly Pitteloud is the chief of the Endocrine, Diabetes, and Metabolism service at the University Hospital (CHUV) in Lausanne, Switzerland. Professor Pitteloud is a specialist in reproductive endocrinology, and her translational research focuses on the neuroendocrine control of human reproduction. She is an expert in the genetics of congenital hypogonadotropic hypogonadism and is the chair of the EU-funded COST European Network investigating GNRH deficiency (www.gnrhnetwork.eu).

(c) 2016 European Society of Endocrinology Printed in Great Britain

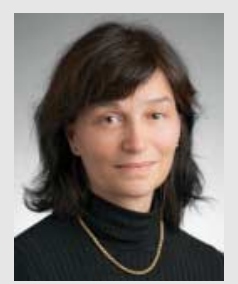

Published by Bioscientifica Ltd. 
are hypogonadal and undervirilized. In addition to these reproductive phenotypes, $\mathrm{CHH}$ patients present with a range of associated non-reproductive phenotypes including anosmia, cleft lip/palate, hearing loss, and a variety of skeletal anomalies that occur at variable rates (1). Regardless of phenotypic expression or degree of $\mathrm{GnRH}$ deficiency, there has been a long-held view that $\mathrm{CHH}$ was a permanent and lifelong condition. Over the past 15 years there have been a growing number of reports of reversible $\mathrm{CHH}$ challenging this dogma. Importantly, these reversals occur well into adulthood, thus differentiating the phenomenon from constitutional delay of growth and puberty wherein pubertal onset is late but occurs spontaneously (5). This review will summarize the literature on the phenomenon of reversible $\mathrm{CHH}$.

\section{Pathophysiology and genetics of $\mathrm{CHH}$}

$\mathrm{CHH}$ is typically diagnosed during the minipuberty of infancy or in adolescence and early adulthood when patients fail to undergo spontaneous pubertal development (1). It is typically classified as normosmic $\mathrm{CHH}$ (when the sense of smell is intact) or Kallmann syndrome (KS) when associated with anosmia. To date, more than two dozen genetic loci have been identified to underlie $\mathrm{CHH}$ (6). Mutations in genes such as GNRH1, GRNHR, $\operatorname{KISS} 1$ or $\operatorname{KISS} 1 R(7,8,9,10,11,12,13,14)$ can impair the action (or secretion) of GnRH, resulting in normosmic $\mathrm{CHH}$. In contrast, mutations in genes impacting the migration of GnRH neurons from the olfactory placode during development (ANOS1, SEMA3A, IL17RD, SOX10 and FEZF1) $(15,16,17,18,19,20,21)$ result in KS. KAL1, recently renamed $A N O S 1$, was the first X-linked gene implicated in $\mathrm{CHH}(15,16,22,23)$. Although mutations in $\mathrm{X}$-linked genes may help account for the fact that there are 3-5 times more males diagnosed with $\mathrm{CHH}$ than females (24), mutations in ANOS1 only account for $\sim 5 \%$ of cases (25). The striking sex discordance may simply represent a bias of ascertainment as females may be under-diagnosed and treated empirically with oral contraceptives. Regardless, as our understanding of the molecular basis of $\mathrm{CHH}$ has accelerated the genetics of $\mathrm{CHH}$ has become increasingly complex. For instance, incomplete penetrance and variable expressivity can be observed in $\mathrm{CHH}$ pedigrees wherein family members harboring the identical mutation exhibit different phenotypes $(26,27)$. Part of this phenomenon can be explained by the interaction of mutations in two or more genes/proteins (oligogenicity) as has been reported in several studies $(19,25,28)$. Further, some patients with reversible $\mathrm{CHH}$ harbor mutations in genes implicated in $\mathrm{CHH}$, (29) including cases of oligogenicity (30). Such reversal cases highlight the importance of environmental (i.e. epigenetic) modifiers on the reproductive axis.

\section{CHH reversibility}

$\mathrm{CHH}$ has been thought to be a congenital and a lifelong disorder. Once diagnosed, $\mathrm{CHH}$ treatment is typically initiated in the form of low-dose sex steroid treatment to develop the secondary sexual characteristics (31) yet pubertal induction can also be effectively achieved using either pulsatile GnRH therapy $(32,33)$ or exogenous gonadotropin therapy (34). All of these treatment options are similar in that they are effective in normalizing serum sex steroid levels.

The notion that $\mathrm{CHH}$ patients could spontaneously recover function of the HPG axis was first raised in a 1975 case report abstract by Rezvani and et al. (35). This was followed by a report of reversal and proven paternity in a fertile eunuch male (36). In the subsequent two decades, additional case reports emerged documenting reversals (37) including fertility/conception $(38,39,40)$ and two series were published demonstrating pulsatile LH secretion in a subset of $\mathrm{CHH}$ men following cessation of treatment $(41,42)$. The first estimate of prevalence of reversal came from Quinton and et al. (43) who depicted five cases among a retrospective cohort of $76 \mathrm{CHH}$ patients revealing a prevalence of $5 \%$. Authors went on to recommend that patients with a testicular volume of $6 \mathrm{ml}$ or greater (i.e. partial pubertal development) undergo biochemical reassessment, particularly if TV increases to $8 \mathrm{ml}$ or greater without gonadotropin therapy of GnRH therapy. This, and subsequent reports, estimated the reversal rate to be in the range of $5-10 \%(29,44)$. Indeed, the first prospective study of reversibility of $\mathrm{CHH}$, identified five reversal cases among a cohort of $50 \mathrm{CHH}$ men suggesting a reversal rate in $10 \%$ of cases (29).

There is some debate regarding the clinical distinction between constitutional delay of puberty (CDP) and $\mathrm{CHH}$ reversal. Delayed puberty is statistically defined (i.e. $2-2.5$ S.D. beyond the mean and thus $\sim 2 \%$ of the population) (5). Both $\mathrm{CHH}$ and CDP are characterized by delayed pubertal onset. In CDGP, puberty eventually starts spontaneously, while $\mathrm{CHH}$ patients typically will not initiate spontaneous pubertal development or have a stalled puberty. For example, when an adolescent male has failed to undergo puberty by age $17(+4$ S.D. for age) (45) the clinical probability of congenital GnRH deficiency $(\mathrm{CHH})$ is very 
high. Notably, as 10-15\% of CHH cases will reverse later in life there appears to be a clinical overlap between CDP and $\mathrm{CHH}$ with these entities existing on a spectrum of $\mathrm{GnRH}$ deficiency. Despite the clinical overlap, relatively little shared genetic basis has been identified between $\mathrm{CHH}$ and delayed puberty $(46,47)$.

\section{Etiology of CHH reversal}

The etiology of reversal is still unclear. In males, reversal was indicated by testicular growth while on testosterone replacement therapy while in females, fertility (i.e. spontaneous pregnancy) has been a key indicator of axis recovery $(30,48,49)$. Interestingly, the common basis among all the cases of reversal was a normal sex steroid milieu for months following sex steroid replacement, exogenous gonadotropin therapy or pulsatile GnRH therapy. As such, some reports have proposed that the reversal phenomenon could be related to the androgendriven upregulation of genes involved in the regulation of GnRH secretion (50). Interestingly, reversal has been noted in patients with severe GnRH deficiency, i.e. in those with a history of cryptorchidism and/or micropenis at birth $(29,49,51)$. Moreover, some reversal patients lack olfactory structures $(44,52)$ pointing to the possibility that recovery of GnRH neuronal function may not always be dependent on intact olfactory structures (53). Interestingly, hypothalamic progenitor cells in rat can give rise to GnRH neurons, suggesting that postnatal genesis of $\mathrm{GnRH}$ neurons can occur in certain circumstances (54). Importantly, mouse studies demonstrate that fetal tissue from the preoptic area of wild-type mice injected into the $3^{\text {rd }}$ ventricle of hpg mice can develop into functional $\mathrm{GnRH}$ neurons (55). This is relevant for when considering reversible $\mathrm{CHH}$ as relatively few $\mathrm{GnRH}$ neurons are necessary for inducing pulsatile LH secretion (56). Further, murine studies suggest that the GnRH system is highly plastic as environmental stimuli such as sexual interactions can rescue $\mathrm{GnRH}$ function in some instances (57). Further, epigenetic influences seem also to play a critical role in the onset of puberty (58), and thus potentially in the reversal process.

\section{Genetic basis of CHH reversibility?}

Unexpectedly, patients with $\mathrm{CHH}$ who undergo reversal can harbor $\mathrm{CHH}$ mutations - indicating that the effects of a genetic defect can be overcome. The first genetic report of a $\mathrm{CHH}$ patient with reversal harboring a homozygous mutation in GNRHR was in 2001 (59). Subsequently, several patients with $\mathrm{CHH}$ reversal were identified with mutations in other genes reported in $\mathrm{CHH}$ including ANOS1 (60), CHD7 (44), FGFR1 (29, 30, 44, 49, 61), HS6ST1 (62), NSMF (49), PROKR2 $(30,52,63)$ and TAC3/TACR3 (51) (Table 1). A recent report of reversal cases identified $\mathrm{CHH}$ mutations in (45\%) of probands (17/38). Mutations were identified in FGFR1 (5/38, 13\%), GNRHR (3/38, 8\%), TACR3 (3/38, 8\%), PROKR2 (2/38, 5\%) as well as TAC3 and HS6ST1 (one each, 3\% respectively) (49). In considering all reports in the literature, mutations in GNRHR appear to be the leading genetic causes among cases of reversal occurring in both homozygous $(48,59,64,65,66)$ and compound heterozygous $(44,66)$ forms. Additionally, a digenic $\mathrm{CHH}$ case has been documented wherein a proband exhibiting reversal carries heterozygous mutations in both FGFR1 and PROKR2 (30). Interestingly, although mutations in ANOS1 (KAL1) and CHD7 occur in $5-15 \%$ of $\mathrm{CHH}$ cases, only two reversals have been found to harbor a mutation in these two penetrant genes (Table 1). Importantly, ascertaining the genetic basis for reversible $\mathrm{CHH}$ is challenging as not all published reports have systematically examined all $\mathrm{CHH}$ genes. Therefore, comprehensive and systematic studies on larger cohorts of reversible $\mathrm{CHH}$ are needed to identify genetic signatures predicting reversal.

\section{CHH reversible among other ethnic groups}

In addition to the previous reports of reversible $\mathrm{CHH}$ in Caucasian probands, reversal cases have now been reported in other ethnic groups. In 2013, a group of Indian investigators reported case descriptions of nine $\mathrm{CHH}$ men who underwent reversal and the recent retrospective study identifying 18 reversals among a large Chinese cohort $(n=354,5 \%)$. The observed frequency among Chinese is lower than other reports yet this may simply reflect different definitions of reversal. In both reports, all cases were males and had received either exogenous testosterone replacement therapy or human chorionic gonadotropin injections $(67,68)$. Further, like our prospective study (29), the common denominator among the reversal cases was a normalized sex steroid milieu.

\section{Fragility of the reversal state}

An important recent development is the growing appreciation that reversal may not be lasting $(44,49,50,65,68)$. Indeed, some patients who recover HPG axis function slip back into a hypogonadal state. While the mechanism(s) 


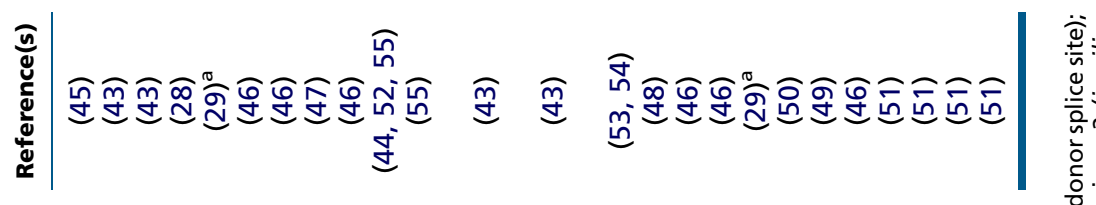

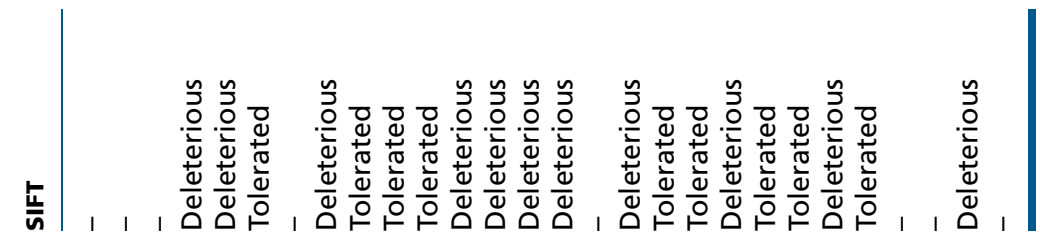

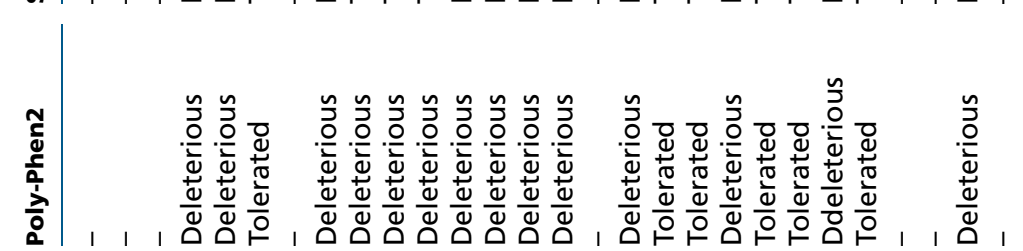

항

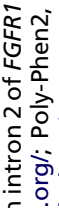

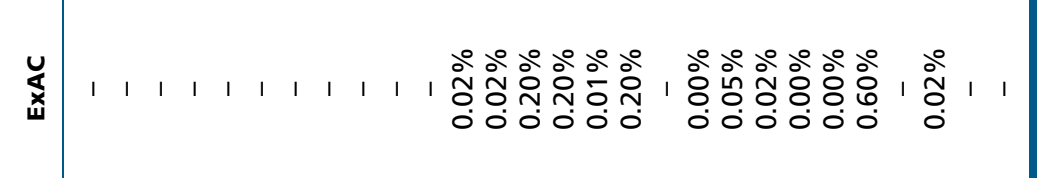
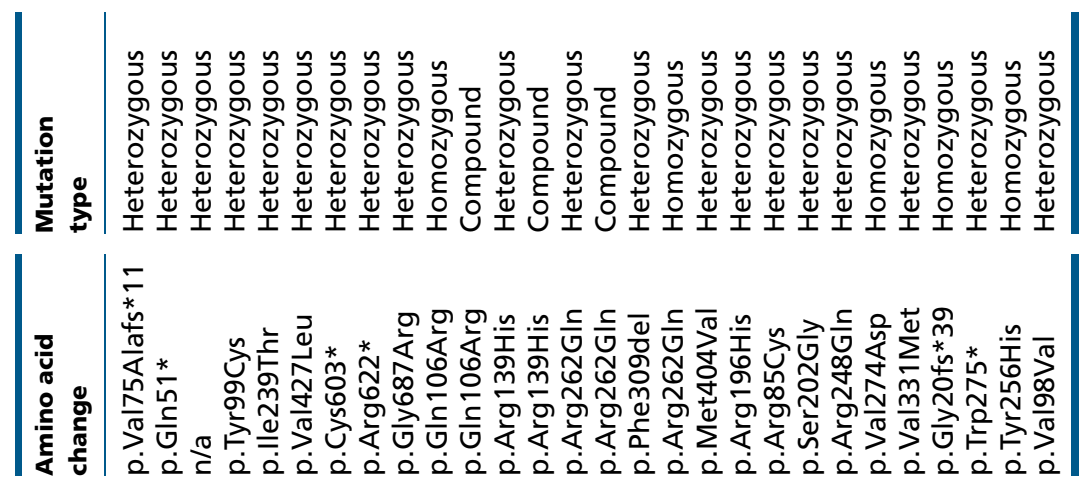

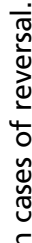
Q

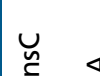<smiles></smiles>

*

等

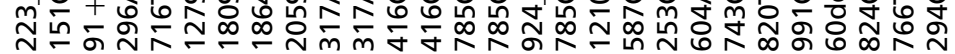
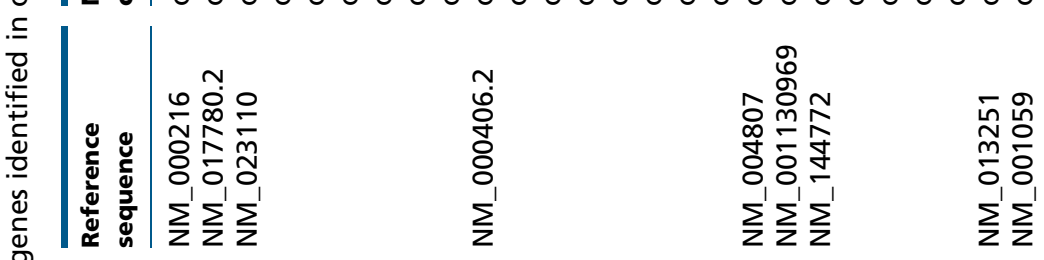

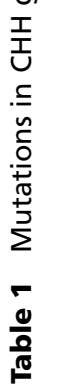

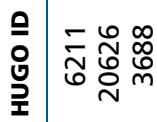

ฐุม

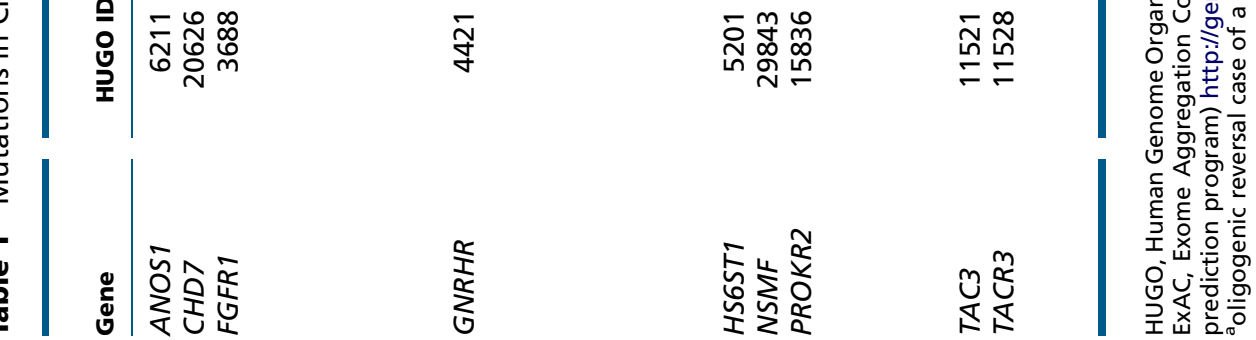

촐 $\stackrel{\infty}{=}$

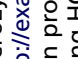

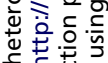

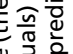

要:

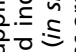

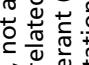

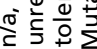

它

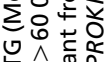

$\varangle 4 \frac{0}{4} \div$

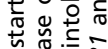

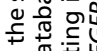

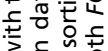

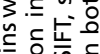

बiv

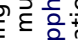

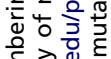

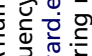

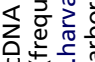

c.

列它

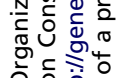


for relapse remain unclear, emotional, metabolic or psychiatric stressors have been implicated in some cases of relapse into hypogonadotropic hypogonadism $(49,50)$. It is tempting to postulate that although these patients were able to sustain normal HPG function for a period of time, the recovered system may be enfeebled and vulnerable to stressors. From this perspective, these $\mathrm{CHH}$ cases share some similarities with hypothalamic amenorrhea (69). To conclude, reversal and relapse underscore an important clinical caveat as there is need for ongoing monitoring of these cases of reversal. While definitive guidelines are lacking for monitoring reversal cases, ongoing surveillance is advisable and annual follow-up seems a prudent recommendation (Box 1).

\section{Box 1 Key points}

1. $\mathrm{CHH}$ is clinically heterogeneous representing a spectrum for $\mathrm{GnRH}$ deficiency

2. Recovery of HPG axis function occurs in $10-15 \%$ of the cases following normalizing the sex steroid milieu

3. Increase in testicular size on testosterone is the most common sign of reversal in males

4. Patients should undergo supervised treatment washouts to assess for recovery (every 2 years)

5. Individuals experiencing reversal should be advised on sperm banking

6. Reversal patients should have ongoing monitoring to assess for relapse

7. More studies are needed to clarify reversals in female $\mathrm{CHH}$ patients

\section{Conclusion}

The traditional dogma that $\mathrm{CHH}$ is necessarily a lifelong condition has given way to the notion that $10-15 \%$ of patients will undergo a reversal of their condition. It is notable that those patients who recover function of their reproductive axis include cases of severe GnRH deficiency and those who harbor mutations in known $\mathrm{CHH}$ loci. The common denominator among the reported reversals has been a normalized sex steroid milieu following treatment. There are several key clinical points including the importance of periodic supervised treatment washouts to assess for $\mathrm{CHH}$ reversibility (every 1-2 years). Specifically, any indication of increased testicular volume in males on testosterone treatment or spontaneous menses in females off treatment should be considered as a likely indicator of reversal. Secondly, patients should be counseled on appropriate use of birth control to avoid the possibility of unwanted pregnancy in the event of reversal. Lastly, it appears that some patients undergoing reversal may be prone to waxing and waning of their reproductive function secondary to stressors. Thus, reversal patients warrant ongoing monitoring and it seems prudent to counsel male reversal patients on the possibility of sperm banking for fertility preservation in the event that they slip back into a hypogonadal state and their spermatogenesis is interrupted.

To conclude, reversal in $\mathrm{CHH}$ is a true phenomenon that has important clinical implications. To date, several questions remain regarding the etiology as well as clinical and genetic predictors of reversal $\mathrm{CHH}$. It is tempting to hypothesize that this reversibility could occur in other developmental disorders.

\section{Declaration of interest}

The authors declare that there is no conflict of interest that could be perceived as prejudicing the impartiality of the research reported.

\section{Funding}

This work was supported by the Swiss National Science Foundation and by COST Action BM1105.

\section{References}

1 Boehm U, Bouloux PM, Dattani MT, de Roux N, Dode C, Dunkel L, Dwyer AA, Giacobini P, Hardelin JP, Juul A et al. Expert consensus document: European Consensus Statement on congenital hypogonadotropic hypogonadism-pathogenesis, diagnosis and treatment. Nature Reviews. Endocrinology 201511 547-564. (doi:10.1038/nrendo. 2015.112)

2 Pitteloud N, Hayes FJ, Boepple PA, DeCruz S, Seminara SB, MacLaughlin DT \& Crowley WF Jr. The role of prior pubertal development, biochemical markers of testicular maturation, and genetics in elucidating the phenotypic heterogeneity of idiopathic hypogonadotropic hypogonadism. Journal of Clinical Endocrinology and Metabolism 200287 152-160. (doi:10.1210/jcem.87. 1.8131)

3 Spratt DI, Carr DB, Merriam GR, Scully RE, Rao PN \& Crowley WF Jr. The spectrum of abnormal patterns of gonadotropin-releasing hormone secretion in men with idiopathic hypogonadotropic hypogonadism: clinical and laboratory correlations. Journal of Clinical Endocrinology and Metabolism 198764 283-291. (doi:10.1210/jcem-64-2-283)

4 Pasqualini RQ. Hypoandrogenic syndrome with normal spermatogenesis. Journal of Clinical Endocrinology and Metabolism 195313 128-129. (doi:10.1210/jcem-13-1-128)

5 Palmert MR \& Dunkel L. Clinical practice. Delayed puberty. New England Journal of Medicine 2012366 443-453. (doi:10.1056/ NEJMcp1109290)

6 Stamou MI, Cox KH \& Crowley WF Jr. Discovering genes essential to the hypothalamic regulation of human reproduction using a human disease model: adjusting to life in the "-Omics" era. Endocrinology Reviews 201536 603-621. (doi:10.1210/er.2015-1045)

7 Bouligand J, Ghervan C, Tello JA, Brailly-Tabard S, Salenave S, Chanson P, Lombes M, Millar RP, Guiochon-Mantel A \& Young J. Isolated familial hypogonadotropic hypogonadism and a GNRH1 
mutation. New England Journal of Medicine $200936 \mathbf{0 2 7 4 2 - 2 7 4 8 . ~}$ (doi:10.1056/NEJMoa0900136)

8 Chan YM, de Guillebon A, Lang-Muritano M, Plummer L, Cerrato F, Tsiaras S, Gaspert A, Lavoie HB, Wu CH, Crowley WF Jr et al. GNRH1 mutations in patients with idiopathic hypogonadotropic hypogonadism. PNAS 2009106 11703-11708. (doi:10.1073/pnas. 0903449106)

9 de Roux N, Young J, Misrahi M, Genet R, Chanson P, Schaison G \& Milgrom E. A family with hypogonadotropic hypogonadism and mutations in the gonadotropin-releasing hormone receptor. New England Journal of Medicine 1997337 1597-1602. (doi:10.1056/ NEJM199711273372205)

10 Layman LC, Cohen DP, Jin M, Xie J, Li Z, Reindollar RH, Bolbolan S, Bick DP, Sherins RR, Duck LW et al. Mutations in gonadotropinreleasing hormone receptor gene cause hypogonadotropic hypogonadism. Nature Genetics 199818 14-15. (doi:10.1038/ng0198-14)

11 Topaloglu AK, Tello JA, Kotan LD, Ozbek MN, Yilmaz MB, Erdogan S, Gurbuz F, Temiz F, Millar RP \& Yuksel B. Inactivating KISS1 mutation and hypogonadotropic hypogonadism. New England Journal of Medicine 2012366 629-635. (doi:10.1056/NEJMoa1111184)

12 Chan YM, Broder-Fingert S, Paraschos S, Lapatto R, Au M, Hughes V, Bianco SD, Min L, Plummer L, Cerrato F et al. GnRH-deficient phenotypes in humans and mice with heterozygous variants in KISS1/Kiss1. Journal of Clinical Endocrinology and Metabolism 201196 E1771-E1781. (doi:10.1210/jc.2011-0518)

13 de Roux N, Genin E, Carel JC, Matsuda F, Chaussain JL \& Milgrom E. Hypogonadotropic hypogonadism due to loss of function of the KiSS1-derived peptide receptor GPR54. PNAS 2003100 10972-10976. (doi:10.1073/pnas.1834399100)

14 Seminara SB, Messager S, Chatzidaki EE, Thresher RR, Acierno JS Jr, Shagoury JK, Bo-Abbas Y, Kuohung W, Schwinof KM, Hendrick AG et al. The GPR54 gene as a regulator of puberty. New England Journal of Medicine 2003349 1614-1627. (doi:10.1056/NEJMoa035322)

15 Hardelin JP, Levilliers J, del Castillo I, Cohen-Salmon M, Legouis R, Blanchard S, Compain S, Bouloux P, Kirk J, Moraine C et al. X chromosome-linked Kallmann syndrome: stop mutations validate the candidate gene. PNAS 199289 8190-8194. (doi:10.1073/pnas. 89.17.8190)

16 Bick D, Franco B, Sherins RJ, Heye B, Pike L, Crawford J, Maddalena A, Incerti B, Pragliola A, Meitinger T et al. Brief report: intragenic deletion of the KALIG-1 gene in Kallmann's syndrome. New England Journal of Medicine 1992326 1752-1755. (doi:10.1056/NEJM199206253262606)

17 Hanchate NK, Giacobini P, Lhuillier P, Parkash J, Espy C, Fouveaut C, Leroy C, Baron S, Campagne C, Vanacker C et al. SEMA3A, a gene involved in axonal pathfinding, is mutated in patients with Kallmann syndrome. PLoS Genetics 20128 e1002896. (doi:10.1371/journal.pgen. 1002896)

18 Young J, Metay C, Bouligand J, Tou B, Francou B, Maione L, Tosca L, Sarfati J, Brioude F, Esteva B et al. SEMA3A deletion in a family with Kallmann syndrome validates the role of semaphorin $3 \mathrm{~A}$ in human puberty and olfactory system development. Human Reproduction 2012 27 1460-1465. (doi:10.1093/humrep/des022)

19 Miraoui H, Dwyer AA, Sykiotis GP, Plummer L, Chung W, Feng B, Beenken A, Clarke J, Pers TH, Dworzynski P et al. Mutations in FGF17, IL17RD, DUSP6, SPRY4, and FLRT3 are identified in individuals with congenital hypogonadotropic hypogonadism. American Journal of Human Genetics 201392 725-743. (doi:10.1016/j.ajhg.2013.04.008)

20 Pingault V, Bodereau V, Baral V, Marcos S, Watanabe Y, Chaoui A, Fouveaut $\mathrm{C}$, Leroy C, Verier-Mine $\mathrm{O}$, Francannet $\mathrm{C}$ et al. Lossof-function mutations in SOX10 cause Kallmann syndrome with deafness. American Journal of Human Genetics 201392 707-724. (doi:10.1016/j.ajhg.2013.03.024)

21 Kotan LD, Hutchins BI, Ozkan Y, Demirel F, Stoner H, Cheng PJ, Esen I, Gurbuz F, Bicakci YK, Mengen E et al. Mutations in FEZF1 cause Kallmann syndrome. American Journal of Human Genetics 201495 326-331. (doi:10.1016/j.ajhg.2014.08.006)
22 Franco B, Guioli S, Pragliola A, Incerti B, Bardoni B, Tonlorenzi R, Carrozzo R, Maestrini E, Pieretti M, Taillon-Miller P et al. A gene deleted in Kallmann's syndrome shares homology with neural cell adhesion and axonal path-finding molecules. Nature 1991353 529-536. (doi:10.1038/353529a0)

23 Legouis R, Hardelin JP, Levilliers J, Claverie JM, Compain S, Wunderle V, Millasseau P, Le Paslier D, Cohen D, Caterina D et al. The candidate gene for the X-linked Kallmann syndrome encodes a protein related to adhesion molecules. Cell 199167 423-435. (doi:10.1016/0092-8674(91)90193-3)

24 Seminara SB, Hayes FJ \& Crowley WF Jr. Gonadotropin-releasing hormone deficiency in the human (idiopathic hypogonadotropic hypogonadism and Kallmann's syndrome): pathophysiological and genetic considerations. Endocrine Reviews 199819 521-539.

25 Sykiotis GP, Plummer L, Hughes VA, Au M, Durrani S, Nayak-Young S, Dwyer AA, Quinton R, Hall JE, Gusella JF et al. Oligogenic basis of isolated gonadotropin-releasing hormone deficiency. PNAS 2010107 15140-15144. (doi:10.1073/pnas.1009622107)

26 Pitteloud N, Durrani S, Raivio T \& Sykiotis GP. Complex genetics in idiopathic hypogonadotropic hypogonadism. Frontiers of Hormone Research 201039 142-153. (doi:10.1159/000312700)

27 Au MG, Crowley WF Jr \& Buck CL. Genetic counseling for isolated GnRH deficiency. Molecular and Cellular Endocrinology 2011346 102-109. (doi:10.1016/j.mce.2011.05.041)

28 Pitteloud N, Quinton R, Pearce S, Raivio T, Acierno J, Dwyer A, Plummer L, Hughes V, Seminara S, Cheng YZ et al. Digenic mutations account for variable phenotypes in idiopathic hypogonadotropic hypogonadism. Journal of Clinical Invesigation 2007117 457-463. (doi:10.1172/JCI29884)

29 Raivio T, Falardeau J, Dwyer A, Quinton R, Hayes FJ, Hughes VA, Cole LW, Pearce SH, Lee H, Boepple P et al. Reversal of idiopathic hypogonadotropic hypogonadism. New England Journal of Medicine 2007357 863-873. (doi:10.1056/NEJMoa066494)

30 Raivio T, Sidis Y, Plummer L, Chen H, Ma J, Mukherjee A, JacobsonDickman E, Quinton R, Van Vliet G, Lavoie H et al. Impaired fibroblast growth factor receptor 1 signaling as a cause of normosmic idiopathic hypogonadotropic hypogonadism. Journal of Clinical Endocrinology and Metabolism 200994 4380-4390. (doi:10.1210/jc.2009-0179)

31 Dunkel L \& Quinton R. Transition in endocrinology: induction of puberty. European Journal of Endocrinology 2014170 R229-R239. (doi:10.1530/EJE-13-0894)

32 Hoffman AR \& Crowley WF Jr. Induction of puberty in men by long-term pulsatile administration of low-dose gonadotropin-releasing hormone. New England Journal of Medicine 1982307 1237-1241. (doi:10.1056/NEJM198211113072003)

33 Delemarre-Van de Waal HA. Induction of testicular growth and spermatogenesis by pulsatile, intravenous administration of gonadotrophin-releasing hormone in patients with hypogonadotrophic hypogonadism. Clinical Endocrinology 199338 473-480. (doi:10.1111/j.1365-2265.1993.tb00342.x)

34 Barrio R, de Luis D, Alonso M, Lamas A \& Moreno JC. Induction of puberty with human chorionic gonadotropin and follicle-stimulating hormone in adolescent males with hypogonadotropic hypogonadism. Fertility and Sterility 199971 244-248. (doi:10.1016/S00150282(98)00450-6)

35 Rezvani I, DiGeorge AM, Rutano J \& Snyder PJ. Delayed puberty and anosmia: Coincidence or Kallmann variant? [abstract] Pediatric Research 19759244.

36 Rogol AD, Mittal KK, White BJ, McGinniss MH, Lieblich JM \& Rosen SW. HLA-compatible paternity in two "fertile eunuchs" with congenital hypogonadotropic hypogonadism and anosmia (the Kallmann syndrome). Journal of Clinical Endocrinology and Metabolism 198051 275-279. (doi:10.1210/jcem-51-2-275)

37 Bauman A. Markedly delayed puberty or Kallmann's syndrome variant. Journal of Andrology 19867 224-227. (doi:10.1002/j.1939-4640.1986. tb00918.x) 
38 Rowe RC, Schroeder ML \& Faiman C. Testosterone-induced fertility in a patient with previously untreated Kallmann's syndrome. Fertility and Sterility $1983 \mathbf{4 0} 400-401$.

39 Bagatell CJ, Paulsen CA \& Bremner WJ. Preservation of fertility despite subnormal gonadotropin and testosterone levels after cessation of pulsatile gonadotropin-releasing hormone therapy in a man with Kallmann's syndrome. Fertility and Sterility 199461 392-394.

40 Wortsman J \& Hughes LF. Case report: olfactory function in a fertile eunuch with Kallmann syndrome. American Journal of Medical Sciences 1996311 135-138. (doi:10.1016/S0002-9629(15)41661-1)

41 Finkelstein JS, Spratt DI, O'Dea LS, Whitcomb RW, Klibanski A, Schoenfeld DA \& Crowley WF Jr. Pulsatile gonadotropin secretion after discontinuation of long term gonadotropin-releasing hormone $(\mathrm{GnRH})$ administration in a subset of GnRH-deficient men. Journal of Clinical Endocrinology and Metabolism 198969 377-385. (doi:10.1210/jcem-692-377)

42 Kadva A, Di WL, Djahanbakhch O, Monson J \& Silman R. Evidence for the Bauman variant in Kallmann's syndrome. Clinical Endocrinology 199644 103-110. (doi:10.1046/j.1365-2265.1996.00650.x)

43 Quinton R, Cheow HK, Tymms DJ, Bouloux PM, Wu FC \& Jacobs HS. Kallmann's syndrome: is it always for life? Clinical Endocrinology 1999 50 481-485. (doi:10.1046/j.1365-2265.1999.00708.x)

44 Laitinen EM, Tommiska J, Sane T, Vaaralahti K, Toppari J \& Raivio T. Reversible congenital hypogonadotropic hypogonadism in patients with CHD7, FGFR1 or GNRHR mutations. PLoS ONE 20127 e39450. (doi:10.1371/journal.pone.0039450)

45 Gerner Lawaetz J, Hagen CP, Grunnet Mieritz M, Blomberg Jensen M, Holm Petersen J \& Juul A. Evaluation of 451 Danish boys with delayed puberty: diagnostic use of a new puberty nomogram and effects of oral testosterone therapy. Journal of Clinical Endocrinology and Metabolism 2015100 1376-1385. (doi:10.1210/jc.2014-3631)

46 Perry JR, Day F, Elks CE, Sulem P, Thompson DJ, Ferreira T, He C, Chasman DI, Esko T, Thorleifsson G et al. Parent-of-origin-specific allelic associations among 106 genomic loci for age at menarche. Nature 2014514 92-97. (doi:10.1038/nature13545)

47 Day FR, Bulik-Sullivan B, Hinds DA, Finucane HK, Murabito JM, Tung JY, Ong KK \& Perry JR. Shared genetic aetiology of puberty timing between sexes and with health-related outcomes. Nature Communications 20156 8842. (doi:10.1038/ncomms9842)

48 Dewailly D, Boucher A, Decanter C, Lagarde JP, Counis R \& Kottler ML. Spontaneous pregnancy in a patient who was homozygous for the Q106R mutation in the gonadotropin-releasing hormone receptor gene. Fertility and Sterility 200277 1288-1291. (doi:10.1016/S00150282(02)03102-3)

49 Sidhoum VF, Chan YM, Lippincott MF, Balasubramanian R, Quinton R, Plummer L, Dwyer A, Pitteloud N, Hayes FJ, Hall JE et al. Reversal and relapse of hypogonadotropic hypogonadism: resilience and fragility of the reproductive neuroendocrine system. Journal of Clinical Endocrinology and Metabolism 201499 861-870. (doi:10.1210/jc.2013-2809)

50 Santhakumar A, Balasubramanian R, Miller M \& Quinton R. Reversal of isolated hypogonadotropic hypogonadism: long-term integrity of hypothalamo-pituitary-testicular axis in two men is dependent on intermittent androgen exposure. Clinical Endocrinology 201481 473-476. (doi:10.1111/cen.12347)

51 Gianetti E, Tusset C, Noel SD, Au MG, Dwyer AA, Hughes VA, Abreu AP, Carroll J, Trarbach E, Silveira LF et al. TAC3/TACR3 mutations reveal preferential activation of gonadotropin-releasing hormone release by neurokinin B in neonatal life followed by reversal in adulthood. Journal of Clinical Endocrinology and Metabolism 201095 2857-2867. (doi:10.1210/jc.2009-2320)

52 Sinisi AA, Asci R, Bellastella G, Maione L, Esposito D, Elefante A, De Bellis A, Bellastella A \& Iolascon A. Homozygous mutation in the prokineticin-receptor2 gene (Val274Asp) presenting as reversible Kallmann syndrome and persistent oligozoospermia: case report. Human Reproduction 200823 2380-2384. (doi:10.1093/humrep/ den247)
53 Moya-Plana A, Villanueva C, Laccourreye O, Bonfils P \& de Roux N. PROKR2 and PROK2 mutations cause isolated congenital anosmia without gonadotropic deficiency. European Journal of Endocrinology/European Federation of Endocrine Societies 2013168 31-37. (doi:10.1530/EJE-12-0578)

54 Salvi R, Arsenijevic Y, Giacomini M, Rey JP, Voirol MJ, Gaillard RC, Risold PY \& Pralong F. The fetal hypothalamus has the potential to generate cells with a gonadotropin releasing hormone (GnRH) phenotype. PLOS ONE 20094 e4392. (doi:10.1371/journal.pone. 0004392)

55 Krieger DT, Perlow MJ, Gibson MJ, Davies TF, Zimmerman EA, Ferin M \& Charlton HM. Brain grafts reverse hypogonadism of gonadotropin releasing hormone deficiency. Nature 1982298 468-471. (doi:10.1038/ 298468a0)

56 Herbison AE, Porteous R, Pape JR, Mora JM \& Hurst PR. Gonadotropin-releasing hormone neuron requirements for puberty, ovulation, and fertility. Endocrinology 2008149 597-604. (doi:10.1210/ en.2007-1139)

57 Rochester JR, Chung WC, Hayes TB \& Tsai PS. Opposite-sex housing reactivates the declining $\mathrm{GnRH}$ system in aged transgenic male mice with FGF signaling deficiency. American Journal of Physiology. Endocrinology and Metabolism 2012303 E1428-E1439. (doi:10.1152/ ajpendo.00289.2012)

58 Lomniczi A, Wright H \& Ojeda SR. Epigenetic regulation of female puberty. Frontiers in Neuroendocrinology 201536 90-107. (doi:10.1016/j.yfrne.2014.08.003)

59 Pitteloud N, Boepple PA, DeCruz S, Valkenburgh SB, Crowley WF Jr \& Hayes FJ. The fertile eunuch variant of idiopathic hypogonadotropic hypogonadism: spontaneous reversal associated with a homozygous mutation in the gonadotropin-releasing hormone receptor. Journal of Clinical Endocrinology and Metabolism 200186 2470-2475.

60 Ribeiro RS, Vieira TC \& Abucham J. Reversible Kallmann syndrome: report of the first case with a KAL1 mutation and literature review. European Journal of Endocrinology 2007156 285-290. (doi:10.1530/ eje.1.02342)

61 Pitteloud N, Acierno JS Jr, Meysing AU, Dwyer AA, Hayes FJ \& Crowley WF Jr. Reversible kallmann syndrome, delayed puberty, and isolated anosmia occurring in a single family with a mutation in the fibroblast growth factor receptor 1 gene. Journal of Clinical Endocrinology and Metabolism 200590 1317-1322. (doi:10.1210/jc. 2004-1361)

62 Tornberg J, Sykiotis GP, Keefe K, Plummer L, Hoang X, Hall JE, Quinton R, Seminara SB, Hughes V, Van Vliet G et al. Heparan sulfate 6-O-sulfotransferase 1, a gene involved in extracellular sugar modifications, is mutated in patients with idiopathic hypogonadotrophic hypogonadism. PNAS 2011108 11524-11529. (doi:10.1073/pnas. 1102284108)

63 Cole LW, Sidis Y, Zhang C, Quinton R, Plummer L, Pignatelli D, Hughes VA, Dwyer AA, Raivio T, Hayes FJ et al. Mutations in prokineticin 2 and prokineticin receptor 2 genes in human gonadotrophin-releasing hormone deficiency: molecular genetics and clinical spectrum. Journal of Clinical Endocrinology and Metabolism 2008 93 3551-3559. (doi:10.1210/jc.2007-2654)

64 Lin L, Conway GS, Hill NR, Dattani MT, Hindmarsh PC \& Achermann JC. A homozygous R262Q mutation in the gonadotropinreleasing hormone receptor presenting as constitutional delay of growth and puberty with subsequent borderline oligospermia. Journal of Clinical Endocrinology and Metabolism 200691 5117-5121. (doi:10.1210/jc.2006-0807)

65 Tommiska J, Jorgensen N, Christiansen P, Juul A \& Raivio T. A homozygous R262Q mutation in the gonadotropin-releasing hormone receptor presenting as reversal of hypogonadotropic hypogonadism and late-onset hypogonadism. Clinical Endocrinology 201378 316-317. (doi:10.1111/j.1365-2265.2012.04493.x)

66 Beneduzzi D, Trarbach EB, Min L, Jorge AA, Garmes HM, Renk AC, Fichna M, Fichna P, Arantes KA, Costa EM et al. Role of 
gonadotropin-releasing hormone receptor mutations in patients with a wide spectrum of pubertal delay. Fertility and Sterility 2014102 838-846.e2. (doi:10.1016/j.fertnstert.2014.05.044)

67 Kulshreshtha B, Khadgawat R, Gupta N \& Ammini A. Progression of puberty after initiation of androgen therapy in patients with idiopathic hypogonadotropic hypogonadism. Indian Journal of Endocrinology and Metabolism 201317 851-854. (doi:10.4103/ 2230-8210.117245)
68 Mao JF, Xu HL, Duan J, Chen RR, Li L, Li B, Nie M, Min L, Zhang HB \& Wu XY. Reversal of idiopathic hypogonadotropic hypogonadism: a cohort study in Chinese patients. Asian Journal of Andrology 201517 497-502. (doi:10.4103/1008-682X.145072)

69 Caronia LM, Martin C, Welt CK, Sykiotis GP, Quinton R,

Thambundit A, Avbelj M, Dhruvakumar S, Plummer L, Hughes VA et al. A genetic basis for functional hypothalamic amenorrhea. New England Journal of Medicine 2011364 215-225. (doi:10.1056/NEJMoa0911064)

Received 20 October 2015

Revised version received 14 January 2016

Accepted 20 January 2016 